\title{
REPORT ON A CASE OF ZENKER'S HYPOPHARYNX \\ DIVERTICLE AND ITS TREATMENT
}

\author{
By
}

M. HOSUI

From Department of Oto-Rhino-Laryngology, Tokyo Teishin Hospital

Zenker's hypopharynx diverticles are relatively rare in Japan when compared to cases reported in Europe and America. A typical case of this disease with the diverticle larger than the size of a walnut was seen in a 56 years old house wife. Operation was done by one stage sac extirpation through left external neck incision and an uneventfull cure was attained after several endoscopic dilatations were performed.

Etiology on evolutionary and pathological factors, sex and age distribution, symptoms, findings, diagnosis and differential diagnosis, histology of sac, and finally various methods of treatment were discussed.

Surgical treatments at present are as follows;

1) Sectioning of the diverticle lip by endoscopy (German method).

2) Sectioning of the sphincter muscle of the so called "Schleudermuskel" (=Pars fundiformis of M. constrictor pharyngeus inf.) by way of lateral neck incision (German method).

3) One stage extirpation of sac body by way of lateral neck incision (English and American method).

\section{Zenker の下咽頚 覣室治験 例 と その治療法等について}

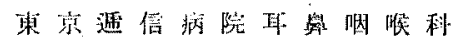

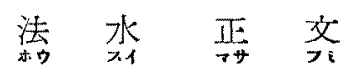

内容目次

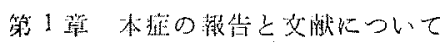

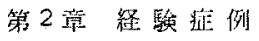

第3 瑟 考按

第 1 節 本定の一般臨朱的硪埧见ついて

1 性，华 令

II 発生覑垠

III 推状

N 哪見, 信断

V嗵理辫見

第 2 節 本症の治療法について

1 保保驸療江

II 手術的撩治

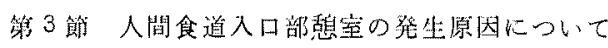

I 進化俩的戊因

II その他の原因

籘4 章結諭

文献

第 1 章 本症の報告と文献について

Zenker の下㸶頭稳室に関する文献は欧米には比䡆的 多く, Zentralblatt でみると外科，耳鼻科两領域儿みら 儿集計はしなからたが每月号に確实に 1〜2 例程度に散

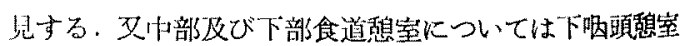
とほ心同数かあるいはやつ少い程度にみら机る。ささて我

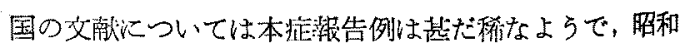

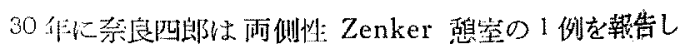
その中でその以前には 記载の明膫なものは8例過ぎ 寸゙，これに反し固有食道憩室症例は 25 例であつたと述 
ベている.

著者は最近 10 年間の医学中央雑誌で 調査したが，奈 良氏以後には昭和 32 年に広戸，執行雨氏の 1 例， 33 年 度に森勝氏の 1 例をみるのみでその以後はみられなから た. これに反し固有食道秝室はや〉多く毎年度 1 例以上 はみられ多い時には 4 例に達する年度むある. 浜之上， 木村氏も昭和 29 年日耳鼻学会発表で 固有食道憩室も最 近 10 年間で 6例に足らないと報告している.いずれに しても我国では下咽頭稳室は固有食道㮩室よりは更に稀 なことは明らかである．従つてその発生頻度等化到って はいずれの交献にも広く言及したものはみなかつた。

第

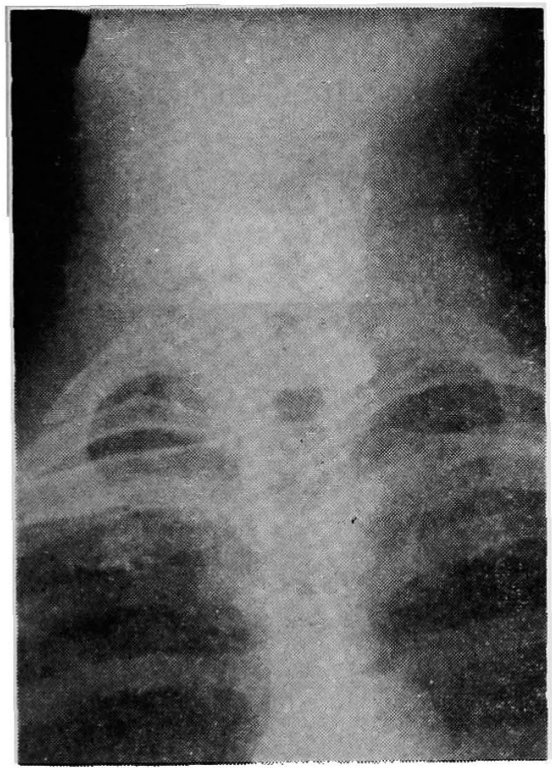

ク，食物の停滞, 固形物の燕下困難, 左頸部の圧迫 感と銿痛，食後時間を経て容易に嘔上をきたす， 粘放分泌過多，夜間安枢不能で時々いきつ゚ぬる感 (choking)，体重減少等をきたすようになつだ、診 察所見では吐物は酸味がなくや〉腐敗臭があるが牛 乳は凝固していない，食道入口部には異常なく両側 梨子状窝にも今回は重液貯溜はみえない、外頸部は 想室が空な時は正常であるが頭を左に向けると喉頭 部がチクチク痛むことがあり，触診では喉頭函の左 端に胸鎖乳様皦の前縁部に 拇指頭大の derb hart な sac をふれる，水を吞ませるとグルグルゴルゴ ルと言うような音がする。体格はやせて $42 \mathrm{kgr} の$ 体重, 血液尿所見は正常である。憩室はレ線写真で

\section{第 2 章 経 験 症 例}

患者は 56 才家婦で既往歴に著患はない，現症歴は昭 和 32 年暮頃から唾液が余計に出ることに気がつき，33 年 1 月に初診したがその時は左梨子状窝に重夜泡沫がた まるのをみるのみで，筋肉その他の運動むよく診断は不 明であつた. 更に 4 月になつて 1 度食べたものが年吐出 してくることが判つたがこれには苦味はなかつた．この 時に初めて食道レ線造影透視を行い，下咽頭後壁に第 1 図写真のような袋を発見，Zenkers Hypopharynxgrenzdivertikel なることを確診した。 しかし当時は未た小 さいので放置しておいたが7 月になると症状が著明にな

図

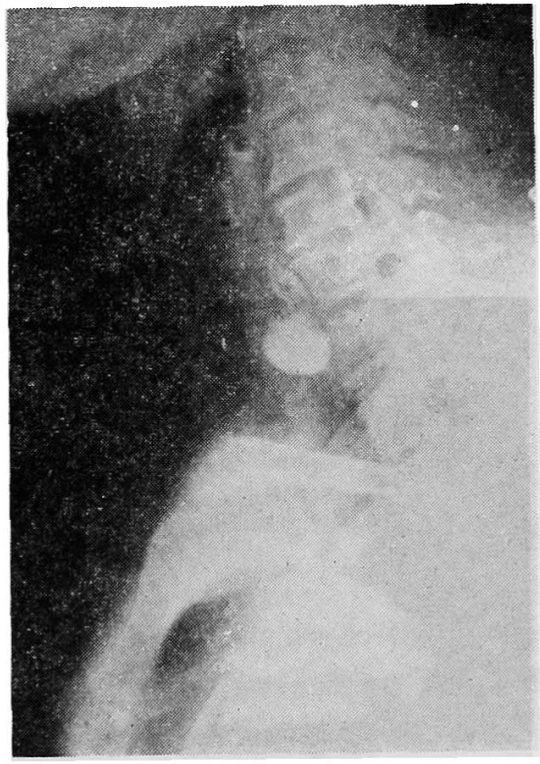

第 2 図

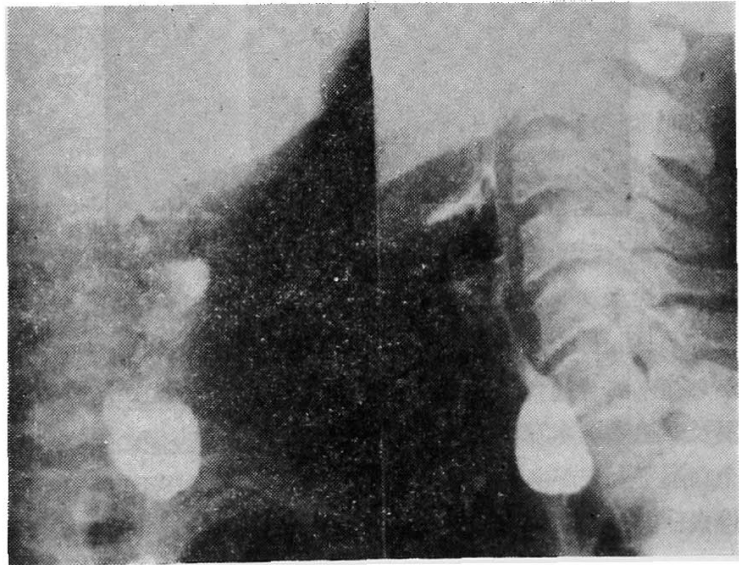




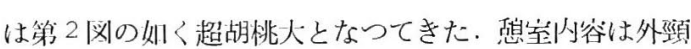
部からの手指圧迫によつて比较的容易に压出し空にする ことができる．以上の如く揹下困難と体重減少が起つて きたので憩室摘出手術を行うことにした。

手術は同年 8 月, 李め下気管切開術走行い気管口より の插管麻酔の下に行つた，先つ左胸鎖孚様筫の前縁に沿. い耳下部から胸骨部迄皮切をを扣き，同符で頸動静脈血管 群を包んで後方に引き掉傷を防ぎ、且術里を広くする，胸 骨甲状筋を前方に引き，上甲状腺動脈を結禁切断し甲状 腺左葉を前方に引き上げると喉頭気管系がみ光，その後 方に接して軟い食道がある。この食道と頸惟骨との間に 予め空にした拇指頭大のほぶ円形の唕室が容易に発見さ れた、食道気管を共にしてその後方を左に嫗転して例方 に引き出すと喤室も側方に出てくる. 喤室自体と食道後 壁との㾑着は幸になく，憵室頸部迄容易に指で剥離可能 である、憩室はうすい、Fascia と Aponeurosisで包ま れているのでこれをよく剝離すると赤黄色平滑な sac と

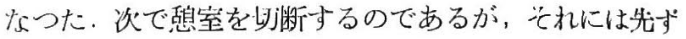
ネラトン管をロから徐々に入れるとこれは全く容易に憩 室に入る，そこで㮩室体を頭方 (proximal) に吊り上げ てネラトン管を押すと初めて管は固有食道に入る.これ らの操作は術創から憩室と食道を明視しつ」行えるので 全く容易且安:全である.かくて食道に入つたネラトン管 を示標として下咽頭後壁自体に侵入しないように䫁室起 始部から $5 \mathrm{~mm}$ 位の所を鉜子で固くはさみそこから一挙 に㓞断する. 唕室の各層は明かにみられこれを沃丁で消 毒し No. 00 chromic cat gut で2回遊走と断続縫合 を行い，更にこの部を内部に埋入入外側觔凅を2 回縫合 し與下圧で空気や水が漏れないようにする. 次で縫合面

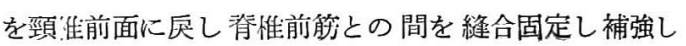

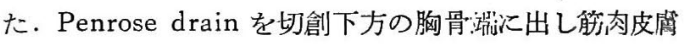
を一次縫合した.これで憩室摘出の one stage operation をしたことになる。

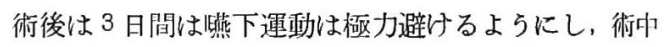

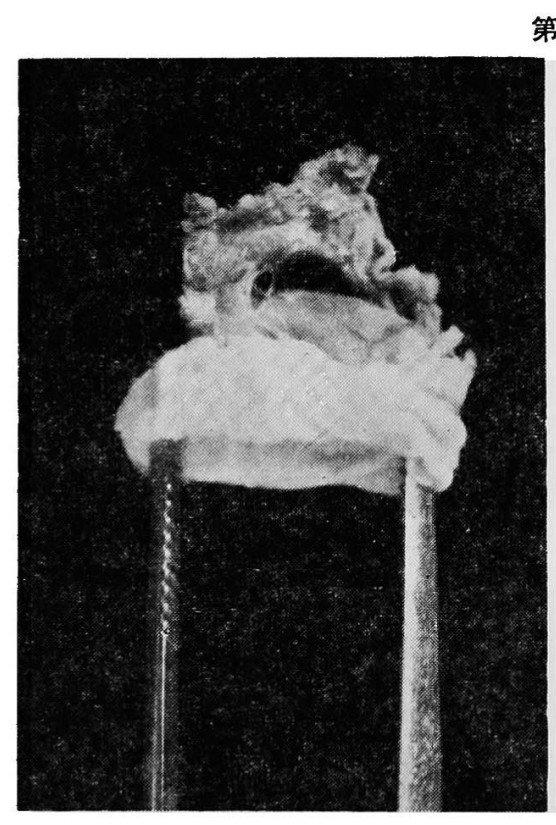

に入れたネラトン管から流動食を与えこの tube feeding は約7 日間行つた。食飼は10日目には軟食とし3週後 から徐々に普通食に戻した。第3 図は摘出した喤室の肉 腿及び組織標本写点である，後者では喤室内表面には完 全な扁平上皮があり，筋肉は装縮し粘嗼下には怪度の慢 性炎症像がみられる．第 4 四は術後 3 週後のし線写真で
3

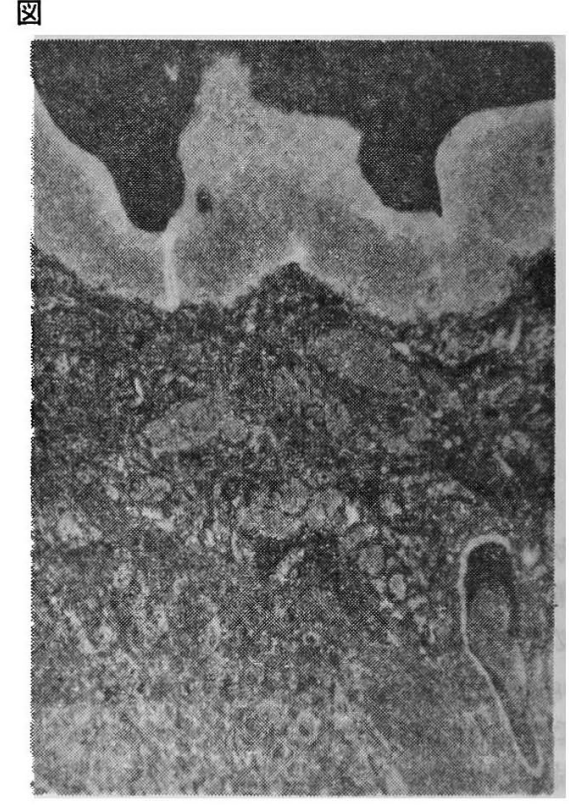

形の変化はあるが食物はよく通過する、第 5 図は約6 週 閒後のものを示寸

術後には当然局所の瘢注性収縮がおこり Pseudorezidivと云われているがこれには食道掘無術がよいの で, 術後 4 力月目から1 カ月 1 回宛数回执張術を行い満 3 年余の今日では症状はなく患者は大いに肥つている。 
第 4 図

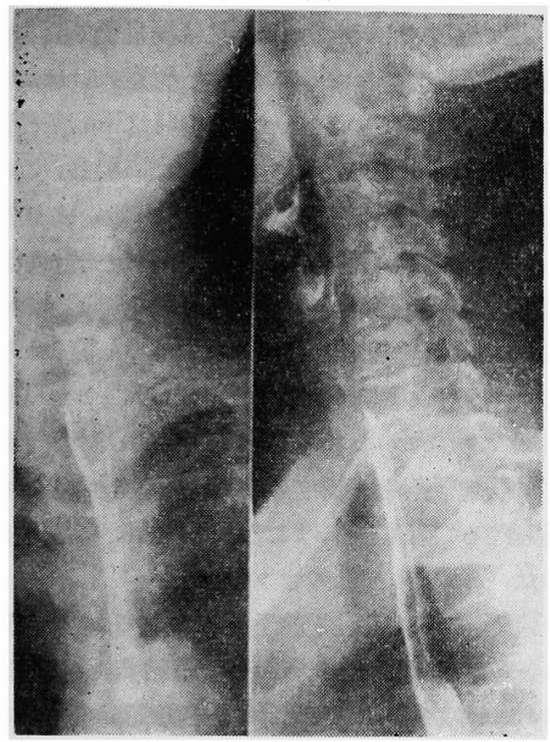

第 5 図

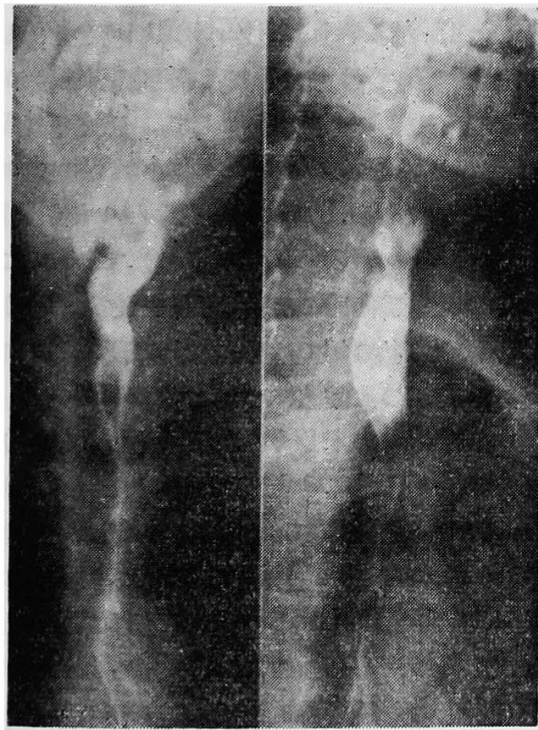

第 3 章 考按

第 1 節 本症の一般臨床的事項について

I. 性, 年令:

本症の発生は性, 年令では Jackson は男に多く70〜 $80 \%$ を占め，30 70 才特沉 50 才以上の中年以上に多い とし，Palmer む約 75\% は男で中年以上であると云う． 又 Lotheissen む6 616 例中 79\% は男で且70\%は50才
以上であると言う、Macmillan は経験 18 例いずれも 40〜83才迄であり，King も15 才以下にはみられない と云う．本症は一般に後天性と言われるが，しかし先天 性と思われる2才，4才の幼児にみられた例も Brintnall や Kriedelbaugh によつて報告されている.

II発生頻度：は各方面の文献をみたが 不明で， Macmillan の 1000 例の Dysphagia の中本症は $1.8 \%$ と言う記載をみたのみである。

III . 症状：は一括すると第6四の表の如くである。

第 6 图 Zenker の下咽頭烈室の自営的症状

1. 食物がつか方る，燕下困奞(固形物）（+)

2. 頸部圧迫感 (t)

3. 頸部異物感 (-)

4. 左頸部鈍痛白

5. 食後時を経て吐く (t) 吐物に\{ $\left\{\begin{array}{l}\text { 胃酸はない } \\ \text { 乳は凝固しない } \\ \text { 敗臭あり }\end{array}\right.$

6. 湢吐は苦しくない (+)

7. 粘液分泌過多而

8. よく咳嗽あり (-)

9. 就寝時秝室内容が流出し安眠不能 (H)

10. 夜いきづまる感あり（Choking）（十）

11. 左頸部に燕下時グルグル音きこえる（十）

12. 体重隇少 (t)

13. Horner 氏症候群がくる (士)

14. 気道に憩室内容吸引することあり（）

15. 右上肺葉の慢性感染

第6図表の右方の $(+)(-)$ は著者経験症例に拈い て夫々陽性，陰性であつたことを示す（11)のグル音と は Gurgling noise, kluckende Geräusch と言われる もので憩室内で空気と食物が 動く時に発生する. (13) の症状は反回神経や 交感神経縁帯 (Grenzstrang) を圧 迫して Ptosis, Myosis, Exophthalmus をきたすことを 示す．（14）では気道に吸引されて脯炎，肺膿瘍をきた すこともある.（15）喤室は通常左頸部にらくれてくる が，Palmer は就瘦時反対側気、道に内容が吸引されるた めか鬼に解妙に右側に多いと述べている。

IV . 所見及び猃断：左頸部に憩室が大きくなり膨隆 するようになればかなり明嘹になる。喉頭鏡所見では憩 室自体は勿論みえないが，梨子状简に泡沫をみることが 最む重要であり殊に一側に Schaum retention をみれ ばその側に㥳室があると v. Eicken は早ぐから述べて いる. 又 Jackson も一側あるいは両側の梨子状筒に泡 沫分泌貯溜をみる時は，上線検査をする迄すなく本喤室 があることは全例に私いて認められると言う、私の場合 


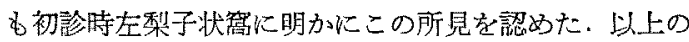

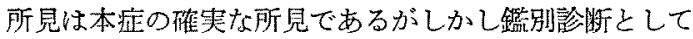
はな乱次の項目に注意を要する。1. 食道蕾瘍，2.局所 の炎症性変化によるbの，3．特発性巨大食道执张症，

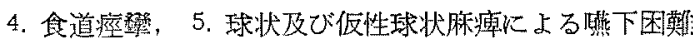

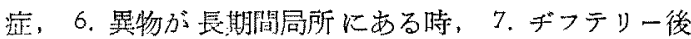

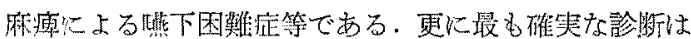
レ綄所見である，造影レ線即見では本宊は縁辺の平滑な 一見明膫な袋状を是する。小さい喤室では側面から透視

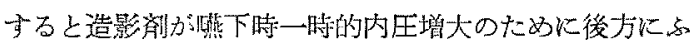

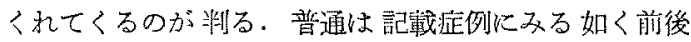
茎には扁平で左右に広い形を呈する．巨大場合には $500 \mathrm{cc}$ も内容のある览頭大沈なることがあると言う、憩 宝殆ど 全てが食道の左側に発達してくるが，この理 由として King は左側怟抗が少く，これは総顽動脈 が左では右より気管食道より離れていること．邓 A. innominata 等の左右の差によるといら. 本症の誉断は レ線所見のみでも充分であるが下咽頭淔道鏡検查を行つ てみると schematisch には第7図のよらな所見が欢ら れると言う。しかし奏際化私が内視鏡愉查を行つた所見 は必ずしもとの通りとは思われなかつた，食物の充满し たある程度大きく発達した sacを発見すれば明磪であ

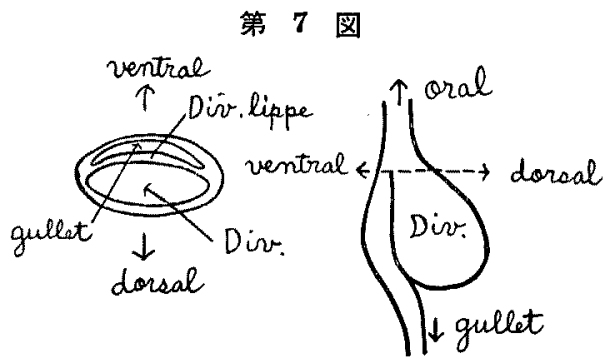

(a)

(b)

るが，瞽室が未だ余り大きくない時は所謂 Divertikel schwelle od lippe は下咽頭部の被壁との区別が非常に

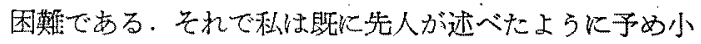
さい鉛玉に黑い系をつけてのま世，これが固有食道に入 つていることをレ線で確めておいて内視鏡を入れると初

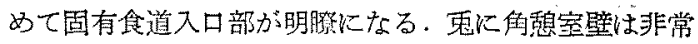
K5すく $2 \mathrm{~mm}$ 内外なので，内視鏡及び消息子操作時 には等孔しないよらに特注意が必要である。食道入口 部の括約等である M. cricopharyngeusは啡下時学除い。 ては常時収縮しているから；直達鏡を入れると先ず初め。

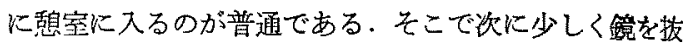
いて前方に位置せしぬ Spatel 又は消息子で固有食道口 を求めるとよい，Starck によると藯室入口部には（a) 入口部が広く開いている場合，この時は下咽頭後壁の直 接の連続としてみえる.（b）ロがせまい場合，この時に は下咽頭後壁に裂隙（spaltförmig）あるいは肛門様に みえる一の 2 型式があると言う。しかし一般注憩室

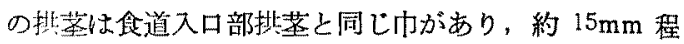

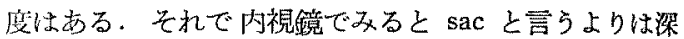
い recessus のよらにみえると言われる。これは私の例 でも同様であつた，しかし最も確実な方法は気管插管麻

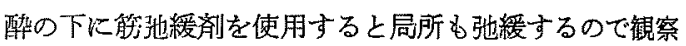
が容易となる、私も後にはこの方法を用いて観察脑張術 を行つた.

V 憩室の病理組織学的所見について：最内側面か

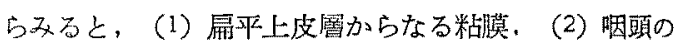
Aponeurosis，(3) たてよこに走る憩室頸部近くに存在

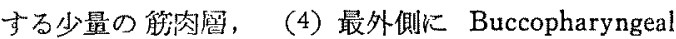
Fascia が文られ，通常柽度の慢性炎症像があり Fibrosis と Plasmacell がみられ Diverticulitis をきたしてい ると言う。私の例です粘膜下には軽度の炎症像がみら れた。こ」で注意すべきことつして，憵室の外周には Elze Beck が述へた所謂 Elze'sche Wundernetz がみられることである。これは外周をとりまく Plexus venosus pharyngeus (Rete mirabile) であり,これが 発洋している時は手術時の剥雄に困難をきたし出血の原 因になると帚う、私の例では幸にこれは認めなかつだ、

第 2 節 本症の治療法について

本症の治療法には古来多くの变遷がみられたが今日な

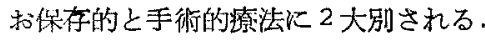

I保存的療法について：Kraus は LeūbeZenker の Divertikelsonde を朋い拨張を行つた。 又 Lotheissen は Balloon を具克た Sonde を入れこれをふくら ませて拡張を行つた，しかしこの方法は手術は縰隔洞焱 等の感染合所症の伧険があるために不可能であつたのが 原因で今日では全く古典的な療法である，しかし保存的 丵法の適応は化学療法が発道した今日においてもなお存 在する. Negus は小さい嚊室では手術は不要でありこ れが発羊し後部縱隔洞 (Henkel's Raum)に入るように なつた時に初めて手術すべきであるとし，Palmer む手 術すべき否やは嚊室の大きさのみが決定要因になると 述べている．この適応による方法としては次のものがす 各。 
（1）小さい唕室では周期的に bag を入れてこれと注 水して Divertikel-schwelle を抬張し，食物が欯室内 に入つてる容易に出てたまらぬようにする。これたより 想室の発達をある程度折制することができる。

(2)これは一種の薬物㙩法であるが憩室の発生には 食道入口部の炎症が一つの原因とされこれは PlummerVinson 在症候とも関俰があると考克られて括り，この 慢性下咽頭炎の治掩として大最の鉄剂の投与法も行和れ

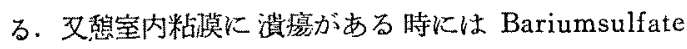

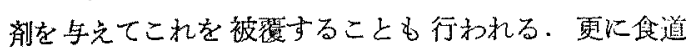

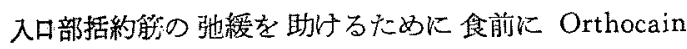
lgr. (Beyer) 等を与完る万法もある。

1 手術的续法について：本法について子古来多く の術式が試みられたが次に簡述すると，

(1) Diverticulopexy 唕室固定法.これは Schmied (1912) が提唱し Hill(1918) が实施した. Displacement method, Transplantation method, Verlagerungsmet-

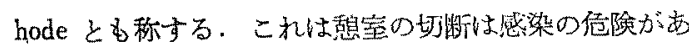
るのでとの代りに外形部成開から入り，愁空体を上方頭 方の咽頭後壁化縫合固定するるのである、これは食物の たまるのを防ぎ一時的には上いが再発又新愻室発生をさ たし易小。

(2) Invaginationsmethode, Einstulpungsmethode. これは Girardや Bevan が行つた方法で欧洲ではBevan's technic として一時広く行われた。これる外项部 から入り尉室を下㸶頚腔内に翻転し押し込みその頸部を

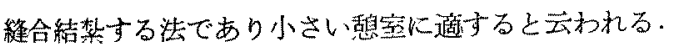
しかしこれにも下咽嘼狭䇤をきた与何除があると云う。 同し目的で米国の Meyer は内視鏡的に㽬室底をつかみ 下咽頭腔内に引き出すと述ぺているが，これは唕室が食 道後壁と痹着又は前述した如くにElze'sche Wundern-

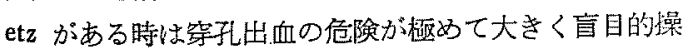
作である。

(3) 2-stage operation method: 先づ想室内に内視 鏡的飞綿をつめておき，一方外頸部切開から入り憼室頸 部を結紮しておくとこの部が 8〜14 日で瘾章する。次で

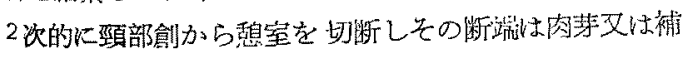

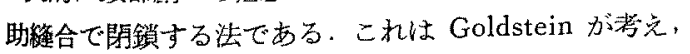
v. Beck が实施したが，愨室頸部絬梦によりその先の 体部が屡々壊通となり，感染瓦期を発生し気管を王迫し 反回神経麻瘦をきたすことがあると言う。

以上の 3 方法はいずれる手術污染による Mediastinitis P Phlegmon の位険を防ぐために教えられた方法
であるが，化学淹法の発造した今日では当然 One stage operation に上る悡室の切断阔出が最も進歩した方法で あり私むこの方法を実施した。

次に現在行われる手術方浩について述べる。現行法の 内にも想室発生理論から将光られた次の上らな夫々買な る方法がある。

(1) Endoskopische Divertikellippenspaltung nach Seifert

これは Mosher (1917) や Seifert (1937) が奏斿し たもので最近の Kirschner の Operationshandbuch (1956)にも Seifert 洗として記載してある。これは内 視鏡的に Killian の言う Schleudermuskel (=sphin-

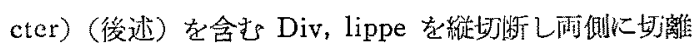
する法で, 約 $2 \mathrm{~cm}$ 程奵盽すると䓝に Div. lippe は開

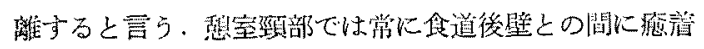
がありこの $2 \mathrm{~cm}$ 以内人 Sphincter が存在与る。それ

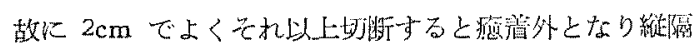
洞桇孔をきたすと云う。器具としては Starck’s Div, sonde, Seifertsche Schere, 少是の出血にはV Vogel 結 禁鋪子がよいと述べている。剪刀の代りに Dohlman (1950)は Electrocoagulation でD. lippeを町ると言 5 .

この方法は憩室発生理論からみると合理的であり，正 しく正中位には血管は少いと述べているが，若し㷂室周 略の大きな血管を町断すると传険であり近接する A. thyreoidea inf, を斯断した出血致死例すあるので全く 安全とは言えないと私性考える。

(2) 外頸部奵閉法による One stage extirpation

これは1890に暊に Bergmann が行つた方法で Nie. hans 法, Mayo 法, Kuttner 法とも称される. 現在最 も進歩した方法で, 要するに患側外頸部切開により入り

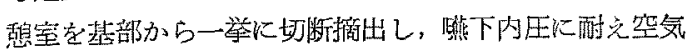

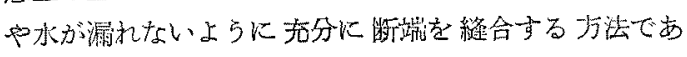
る.私もこの方法な行つた。

こつで更に術式等について若十述べてみると，䀧酸

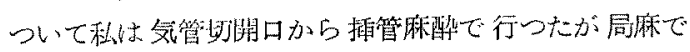
も可能であり，又全麻では第 5,6頸䊒からの Epidural Block anaesthesie と Vagus の Block Anaesthesie で

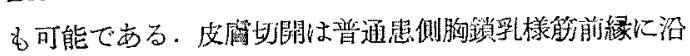
つて行うが，水平位の Collor incision を行らと美容上

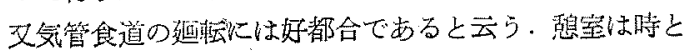
して発見困難なことありと言われるが気管食道を共にし て廹転すると㘥状顿骨の後方に必ず発見され，指でられ 
しごいてみるとよく判ると言う．Jackson はこの際内視 鏡を礉室内に入れ内側から照明して発見を容易ならしめ る Endoscopic illumination 法がよいと述べている. 反回神経についてはこれは気管食道の中間の側方にある ので，この両者を共にして迴転する限り損傷の恐れはな い. 私の経絤では憩室切断については固有下咽頭腔に侵 入しない上らに，文少し残しすぎると再発や棚形成の原 因となるのでこの毠室切断が最も注意を要すると思われ た. 多くの文献では 5〜 $10 \mathrm{~mm}$ 程度で断断し充分に縫 合を行らと記載している. 又術後の tube feeding につ いては色々の説がある。本法は不要で 4 日目から夜体食 を与劣るの，又 tubeは2 日間でよいと言う説もあ る。私は7日間入れて拈いた。普通食は Nissenは10 日目, Sweet は14 日目, Jacksonは30日目から与古る と言う。私は10日目から軟食20日目から普通食を与之

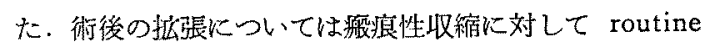
として数回拨張をするのがよいと言う.Jackson は手術 53 例中 15 例に術後摭張術を数回したと述べている.

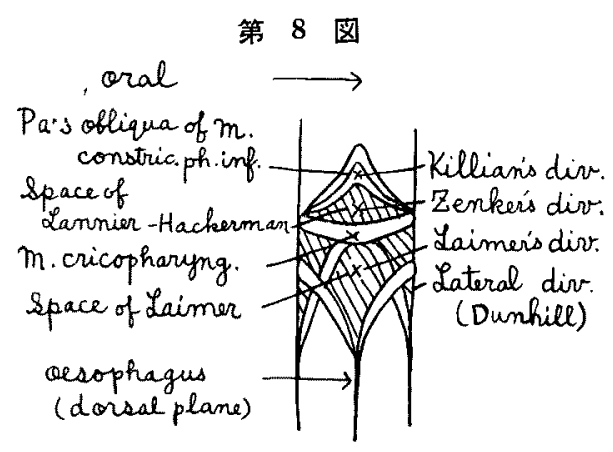

更に注目すべきは現在の外頸部切閉法についても唕室 発生理諭により次のように異なる説がみられることであ る、下㸶頭から食道入口部にかけての憩室の発生原因に いては次の考えがほら゙定説となつている，第8図にみ るように下咽頭収縮笳の後面下縁の Pars obliqua の值 上には血管通過孔による Locus minoris がありこ〉

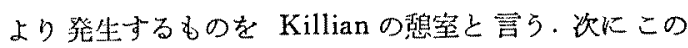
Pars obliqua と同じ下㸶頭収縮䶼ではあるが水平汇近 く走る M. cricopharyngeus (=sphincter) との間には 後壁に図にみる如く，Space of Lannier-Hackerman と 言う笳肉に乏しい三角部があり，この部が内压に弱い Locus min. となり herniation を起して生ずるものを Zenker の蒩室と言う. Killian と Zenker 両唕室発生 部位には約 $2 \mathrm{~cm}$ の巨離がある.更に Zenker 喤室から
䄪 $1 \mathrm{~cm}$ 下方の食道後壁には M. cricopharyngeus の直 下にほぶ菱形をなす能肉にそしい Space of Laimer が あり、この部より生ずるものを Laimer の悡室と言う. 又この両側部からも稀に Lateral diverticle (Dunhill) が発生すると言ら. 更に Raven は後天性の下晒頭前壁 の内圧性憩室をみたと言う。しかしこれらの内 Zenker の賏空が最も普通で多くみられる。

Zenker の慗室の発生原因については，下咽頭收縮觔 の神経支配は Pharyngeal Plexus と迷走神経の N. laryngeus sup. 支による 2 本から受汁て扣り，更にこ れは M. cricopharyngeus では反回神経（多くは左侧 から）や交㹂神経からも支配を受计ている。このように 神経支配の異なる上記䶼肉束間では相互間の収縮と弛緩 の協調不一致が起り，異常内圧の增大をきたし hernia が起るとされている、以上の上うな説からたと悡室の

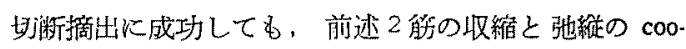
rdination が不調なる限り再発も可能なわけである. 従 つてこの点から次の上うな翼なる手術方針が出てくる。

1. 独乙の Killian は Pars fundiformis des M. cricopharyngeus 即ち彼の言う“Schleudermuskel” が環状軟骨の下 $1 / 3$ 亿附着し強い sphincter となつて いるのでここれを切断することが蒩室手術の主なる目的 であり喤室目体の摘出は従である，其故に場合によって は前述の Seifert 氏法の如くSchleudermuskel 含め た Divertikellippe を内視鏡的に或䒽するだけでもよい と言う．これは先年来日諢演した Prof. Hermann 当同 し考えで，彼は sphincterをよく露出して中心一力所で なく左右 2 力所で切鹳すると再発しないと述べた。これ に対儿,

2. 米国の Chevarier Jackson はこの Sphincter を “pinch cock muscle”と称したが，これを具溦するこ とには全くふれていない、想室さ兄切断摘出すればよい と述べて拁り，これは Palmer やSweet 屯同し意見で ある. 又この中間説もあり，

3. 英国の Dunhill はこの sphincter を"sling muscle”と称したが彼はこの朌肉をゆるめればよいと し，それにはこの漩収縮を支配する交感神経あるいは

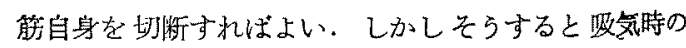
胸厡内陰王に 対して 食道入口部が開いて所請食道呼吸 (Aerophagie) が起り，次第に食道が空気でらくれてき て肺呼吸が困難になるからこの説には賛成できないと言

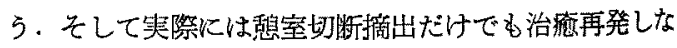
いことも事害多数あると述べている. 
この Dunhill の食道呼吸出現に関する意胃は理論的 には正しいと思われるが，一方 Killian の Sphincter 切断法も恶室再発防止の点では合理的と思われるが，彼 は食道呼吸発生については全くふれていない.このよう に英米学派と独乙学荡とでは治療法が全く巽なつている 点㹥目すべき事である、経験の少い私はどららがよい のか現在全く不明である。しかし私の手術絟賗で，外

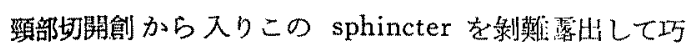
に切断することはかなりの経験を要すると思われ，䶊室 自体の切断摘出の方が容易であると思われた。

第3 節 人問食道入口部燱室の発生原因について

I 進化諭的成因：これには Negus 等の興昧ある 論交があるが，要するに形態的機能的憩室成计素因とし て（1）人間は直立し，(2) 前肢による複雑な忖静又重 量举上が可能となつたこと（3）面治により頭盖底と会 椎との前面角度が小さくなり，又下靧は他の動物より後 退し，これに伴い㩔頭は下降し，咽頭は長く大きくなり 吹口蓋之挣頭蓋は分離したこと，等により大いに進化し 文明発展をきたしたが，半面これらの特徴の影譩によ D, (1) 形態的火は M. constrictor pharyngeus inf. が下方に延長して斜走し, M. cricopharyngeus は食道 呼吸を防き且前肢力を作り arm effect を充分にするた ぬに水平強く発達したので，その中間に Locus minoris を生じたこと.（2）機能的には，䠐下時には言語 機能により大さく発達した咽頭喉頭は共に上万に举上さ れるが，食道は下端が横漂膜に固定しているので上端も 移轩不能でそのために下咽頭部が引き延ばされて翙くな ること等の素因をさたしこれにより㓤室発生を容易なら しめるに到つたと言う。

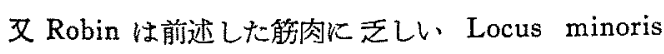
には腮㩐の残りがみられ，更に Ductus thymicusがあ りこれが憩室発生の基因をなすと言う，我国では広戸，

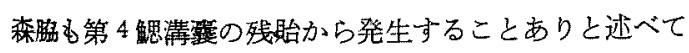
いる.

Iその他の原因：以上の生理的素因の他に次のよ

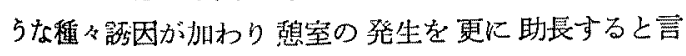
5.

1) 慢性の下咽頊炎があると刺战症状がつぶき括䄪筋 の正常な弛緩を妨げる (Negus 等). 時にこれは Plummer-Vinson 民庭状の一部をなすこともある。

2）上記炎症が治疹してb局所の瘢狭狭窟をきたすこ

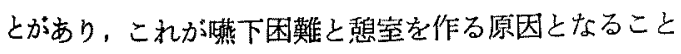
がある。

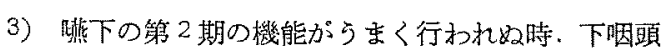

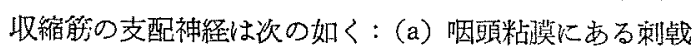
受容带 (Pharyngeal Plexus, Pommerenk'es area 二古 根, 軟口蓋や咽頭後壁に分在して食物刺战により反射的

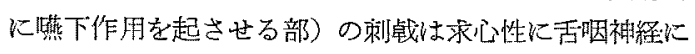

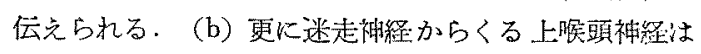

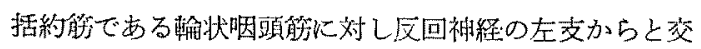

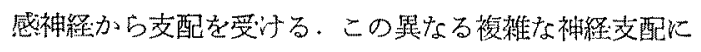
よる調和が得られず，咽須腔の繀小と食道入口部括約的

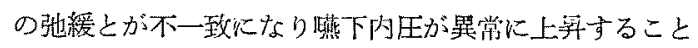
がある．正常位では下咽頭後壁の Locus minoris は脊 椎前壁に接しているから後方に凸出することは不能であ るが，嬹下时には啹頭は前上方に移動し㸶頭も収維する のでこの時には咽頭後壁に間裳を生じ hernia 形成が容 易となる.

4) a. Lannier-Hackerman $の$ muscle missing space が著明な場合。

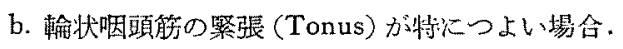

c. 甲状娷骨化骨の高度な場合.

d. 甲状腺の発達の上い場合.

e. 甲状㽞骨, 梨子状窝, 食道入口部の不対称性が ある場合.

これらの条件が基盤となりこれと機械的原因が加わり発 生すると言う (Schönung, Guisez, Boeninghaus).

5）素因のある場合には大食塊を、吞込を等の一同の Trauma で束発生する (v. Eicken).

6) Elze'sche Wundernetz が発连していると那櫬静

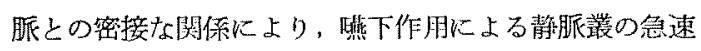
な空と冭満が起りこれが発生原无となると言う（Beck. Boenninghaus).

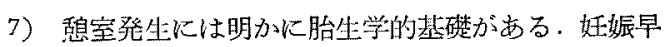
期の胎傴には posterior pharyngeal pouch がみられる が、これは普通は後期に完全に消失すると言う(Mosher の先天性菜因説).

8）男に王倒的に多く且思春期以前にはみられないの

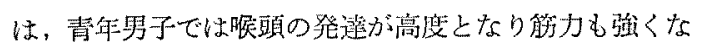

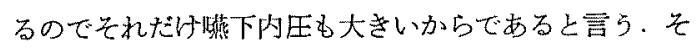

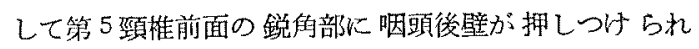
て，その部の筋肉のない粘膜がうすくなることも原因て あると言ら (B.T. King).

\section{第 4 章 結 論}

56 才家婦に発生した定型的な Zenker の下咽頭唕宝 O One stage opeation による摘出治療例家还心，次で 
本症の症状, 熼断, 治療法, 本症の発生原因等について 述べた、就中治療法については現在最も進歩した手術法 について述へ，この方法の内にも唕室発生理論からみて 独乙学㳖と英米学泟之の間には手術術式に和いて全く異 なる興味ある点があることを述べた。

\section{主要文献}

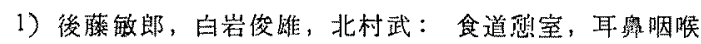
科学 (下潦)，1360，1960， 2) 向野興滩：食道の Curlingについて，気食会報，9巻3号，1928. 3)

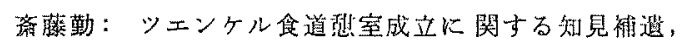
耳奥臨床，20巻，339，1927.4）奈良四郎：雨僋

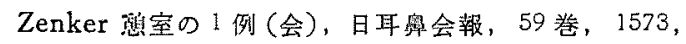
1926. 5) 中山樰明：食道態室, 日本外科全書, 17 巻, 306.6$)$ 浜之上信博, 木村良一：最近経験せ

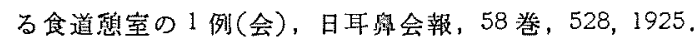

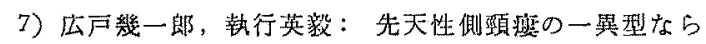
びに Grenzdivertikel の成因に関する考察，耳鼠臨床， 50 巻，140，1957. 8) 森脇良省：食道菿室の1例 (会)，日耳與会報，61巻，982，1928。9）山川強四 郎：食道烈室, 日耳舅全書, 第 4 巻, 食道糄. 10) Blumenfeld und Jaffé; Divertikel des Oesophagus, Pathologie der Oberenluft-und Speisewege 276, 1931. 11) Botelho, $A, A, J$.: Pharyngo espophageal Diverticulum. A.M.A. Arch. of Otolaryngology, Vol. 69 , 595, 1959. 12) Brintnall, E.S., and Kriedelbaugh, $W . W$. Congenital diverticulum of the posterior hypopharynx simulating atresia of the esophagus.

Ann, Surg, 131, 1950. 13) Coates, Schenck, Miller.: Diseases of Oesophagus, Otolaryngology, Vol, V, chap, 11, 30, $1958 . \quad$ 14) Denker-Kahler: Pulsionsdivertikel des Hypopharynx. Handbuch d. Hals, Nasen-Ohren Hlkde, Bd, 9. 285, 1925.

Denny, W.R., Wilson, C.P.: Pharyngeal Diverticula A.M.A. Arch. of Otolaryngology Vol. 67. No. 5, 1958. 16) Dunhill, T.,: Pharyngeal Diverticulum Brit. Jour. Surg., Vol. 37, 404. 1950. 17) Jackson and Jackson.: Hypopharyngeal Diverticulum. The Diseares of Nose, Throat, and Ear, 593, 1947.
Jackson, C., Norris, C.: Pharyngeal Diverticulum and the technique of its surgical treatment. Laryn. goscope. Vol. 65, 546. 1955. 19) Kesseler, H.J;, Maier, H.C.: Diverticulectomy as treatment for traumatic perforation of pharyngoesophagel diverticulum. Am. J. Surgery. Vol. 90. 994. 1955. 20) King, B.T: New, concepts of the etiology and treatment of diverticula of the oesophagus. Surgery; gynecology and obstetrics. Vol. 85. 93. 1947. 21) Kirschner, M.: Operative Bhdg. der Zenker'schen Grenzdivertikel (Denecke, H.J., Guleke, N.) allg, u. spezielle Chirurgische op. lehre. Bd, 5, 488. 1956. 22) Lahey, F.H.: The management of pulsion Esophageal Diverticulum. J.A.M.A. 1415. 1937. 23) Leggeri, A., Andreassi, F: Contributo allo studis dei diverticoli faringo esofagei (Patogenesi-sintomiterapia) Arch. chir. Torace. 14. 279. 1960.

v. Legler, u.: Unter welcher Voraussetzungen ist die endoskopische Op der Zenker'schen Divertikel zu verantwortet? Zeitschr. f. Laryngologie, Rhinologie " Otologie Bd. 39. 405. 1960.25$)$ Negus, $V, E$, Pharyngeal diverticula. Observation on their evolution and treatment. Brit. Jour. of Surg. Vol. 38. No. 150, 1950. 26) Nissen, R.: Operation des Pulsionsdivertikel des Halsteiles. Operation am Oesophagus. 52. 1954. 27) Palmer, E.D.: Divertic* ulosis. The Oesophagus and its diseases. 96. 1952.

28) Robin, I.G.: Pharyngeal Diverticula Med. Press. Vol. 243. 99. 1960. 29) Solis-Cohen, L., Ersner, $M$, Friedman, $P, S$, Multiple pharyngeal and esophageal Diverticula, Hiatal hernia of the stomach and chalasia of esophageal cardiac junction. Am. J. Roentgenology, Vol. 75. 242. 1956. 30) Sweet, $R, H .:$ Diveticulectomy. Thoracic surgery, 246 . 1951 .

(原穆到洋二昭和 37.2 .23 日) 